\title{
Water footprint of crop production for different crop structures in the Hebei southern plain, North China
}

\author{
Yingmin $\mathrm{Chu}^{1,2}$, Yanjun Shen ${ }^{3}$, and Zaijian Yuan ${ }^{4}$ \\ ${ }^{1}$ School of Management, China University of Mining \& Technology, Xuzhou, 221116, Jiangsu, People's Republic of China \\ ${ }^{2}$ Guangdong Science and Technology Library, Guangzhou, 510070, People's Republic of China \\ ${ }^{3}$ Center for Agricultural Resources Research, Institute of Genetics and Developmental Biology, Chinese Academy of \\ Sciences, Shijiazhuang, Hebei, 050021, People's Republic of China \\ ${ }^{4}$ Guangdong Key Laboratory of Agricultural Environmental Pollution Integrated Control, Guangdong Institute of \\ Eco-environment Technology, Guangzhou, 510650, People's Republic of China
}

Correspondence to: Zaijian Yuan (selfsurpass@163.com)

Received: 30 August 2016 - Discussion started: 18 October 2016

Revised: 1 March 2017 - Accepted: 11 May 2017 - Published: 26 June 2017

\begin{abstract}
The North China Plain (NCP) has a serious shortage of freshwater resources, and crop production consumes approximately $75 \%$ of the region's water. To estimate water consumption of different crops and crop structures in the NCP, the Hebei southern plain (HSP) was selected as a study area, as it is a typical region of groundwater overdraft in the NCP. In this study, the water footprint (WF) of crop production, comprised of green, blue and grey water footprints, and its annual variation were analyzed. The results demonstrated the following: (1) the WF from the production of main crops was $41.8 \mathrm{~km}^{3}$ in 2012 . Winter wheat, summer maize and vegetables were the top water-consuming crops in the HSP. The water footprint intensity (WFI) of cotton was the largest, and for vegetables, it was the smallest; (2) the total WF, WFblue, WFgreen and WFgrey for 13 years (2000-2012) of crop production were $604.8,288.5,141.3$ and $175.0 \mathrm{~km}^{3}$, respectively, with an annual downtrend from 2000 to 2012; (3) winter wheat, summer maize and vegetables consumed the most groundwater, and their blue water footprint (WFblue) accounted for $74.2 \%$ of the total WFblue in the HSP; (4) the crop structure scenarios analysis indicated that, with approximately $20 \%$ of arable land cultivated with winter wheatsummer maize in rotation, $38.99 \%$ spring maize, $10 \%$ vegetables and $10 \%$ fruiters, a sustainable utilization of groundwater resources can be promoted, and a sufficient supply of food, including vegetables and fruits, can be ensured in the HSP.
\end{abstract}

\section{Introduction}

Due to excessive water usage, freshwater scarcity has become a threat to human society (Dong et al., 2013). Worldwide, the largest freshwater consumer is agriculture, consuming more than $70 \%$ of the world's freshwater (UNEP, 2007; Lucrezia et al., 2014). Water resources have been heavily exploited by agriculture worldwide (Konar et al., 2011) and, to ensure the increasing food demand, global water consumption has almost doubled during the past 40 years (Gleick, 2003), and future water use for food production will continue to be influenced by population growth and changes in dietary preferences (Rosegrant and Ringler, 2000), which will lead to the consumption of more water resources. China is a freshwater-poor country, with approximately $2100 \mathrm{~m}^{3} \mathrm{yr}^{-1}$ of water resources per capita, accounting for only $28 \%$ of the world's per capita share. The spatial mismatch between water and arable land reinforces China's water challenge. About $70 \%$ arable land in the north of the Yangze River contains only approximately $17 \%$ of the national total water resources. Due to the current water shortage in the area north of the Yangze River, the NCP is facing its most severe water scarcity issue. The NCP presently contains only $1.3 \%$ of China's total available water, with $225 \mathrm{~m}^{3} \mathrm{yr}^{-1}$ per capita (White et al., 2015).

As a method to assess the water use of production systems, the water footprint (WF) concept was proposed (Heokstra, 2003), which includes direct and indirect water usage of a 
consumer or producer (Hoekstra et al., 2009). In recent years, many researchers have used the WF to evaluate water use in agricultural production (Bocchiola et al., 2013; Chapagain and Hoekstra, 2011; Chapagain and Orr, 2009; Gheewala et al., 2014; Jefferies et al., 2012; Lamastra et al., 2014; Mekonnen and Hoekstra, 2010; Shrestha et al., 2013; Y. B. Wang et al., 2014; X. Wang et al., 2015; Xu et al., 2014; Zang et al., 2014; Suttayakul et al., 2016). The WF of crops reflects the water consumption of different crops, and can focus on local crop products. For each crop, the blue WF (WFblue) refers to the volume of irrigation water consumed, the green WF (WFgreen) is consistent with the effective rainfall for plants, and the grey WF (WFgrey) represents the volume of water required to dilute pollutants to the agreed maximum acceptable levels (Hoekstra and Chapagain, 2007). Since the water consumption of each crop is different, the WF for different crops varies greatly. Xu et al. (2014) analyzed the WF of six kinds of crops in Beijing from 1978 to 2012, and found maize accounts for $57 \%$ of the green WF and $46 \%$ of the grey WF, vegetables account for $45 \%$ of the blue WF, and wheat accounts for $26 \%$ of the total WF. X. Wang et al. (2015) found that winter wheat conserved approximately $1.9 \times 10^{9} \mathrm{~m}^{3} \mathrm{yr}^{-1}$ of WFblue from 1998 to 2011 in the Hebei Plain.

The Hebei southern plain (HSP) was selected as the study area. It is located in the northwest of the NCP and has approximately $4.0 \times 10^{4} \mathrm{~km}^{2}$ of arable land (accounting for approximately $13 \%$ of the NCP and $3 \%$ of China's total). In 2008, the HSP produced approximately $2.7 \times 10^{10} \mathrm{~kg}$ of grain (accounting for approximately $5 \%$ of China's total) that had a water consumption of approximately $3.0 \times 10^{10} \mathrm{~m}^{3}$ (Yuan and Shen, 2013). The over-exploitation of groundwater in this region has had devastating consequences: the groundwater table has decreased by more than $20 \mathrm{~m}$ within the past 30 years (Chen et al., 2003). Because the WF of various crops is different and the crop structure of a region reflects the proportion of various crops growing within that region, the WF of the crop structure can illustrate the entire agricultural water consumption of that region. The study of the WF for crop structures can help promote the sustainable utilization of water resources for agriculture, and can be particularly valuable for areas facing water shortage.

The main aims of this study were (1) to quantify the WF of production of main crops in the HSP from 2000 to 2012 and (2) to discuss a reasonable crop structure based on the WF analysis for different crop structure scenarios. In this study, we propose a suitable crop planting structure for this region, and support the development and implementation of policies on agricultural water management.

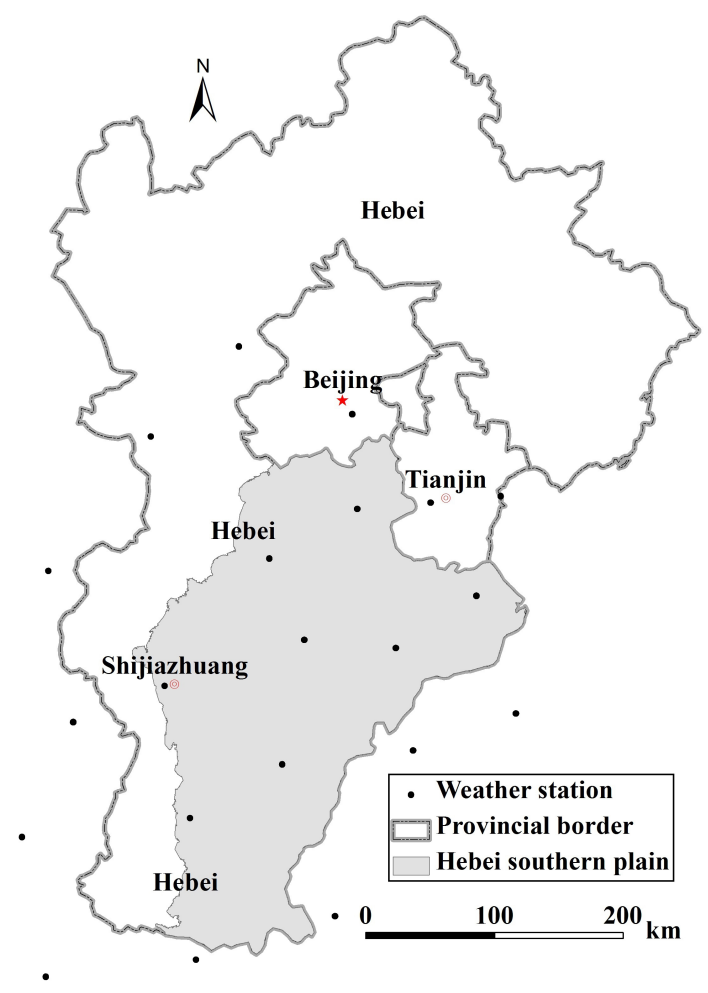

Figure 1. Location of the Hebei southern plain.

\section{Materials and methods}

\subsection{Study area}

The Hebei southern plain $\left(114^{\circ} 20^{\prime}-119^{\circ} 25^{\prime} \mathrm{E}, 36^{\circ} 03^{\prime}-\right.$ $39^{\circ} 56^{\prime} \mathrm{N}$ ), with an area of approximately $62000 \mathrm{~km}^{2}$, is located in southern Beijing and Tianjin (Fig. 1). The climate in this region is temperate monsoon, with a mean annual precipitation of $550 \mathrm{~mm}$ and a mean annual temperature of $11.5^{\circ} \mathrm{C}$. Precipitation has a non-uniform distribution throughout the year, and approximately $80 \%$ of the total precipitation occurs from July through September. In the HSP, most arable lands are irrigated by groundwater, except in the eastern part, where there is saline shallow groundwater. The primary crops in the plain are wheat, maize (including summer maize and spring maize), cotton, and peanut; the main vegetable crops are Chinese cabbage, celery, cauliflower, onion, bean, rape, leek, coriander, and fennel; and the main fruits are apple, pear, jujube and grape.

\subsection{Data collection}

The meteorological data from 21 weather stations (Fig. 1) around the HSP, including daily maximum temperature, minimum temperature, average temperature, wind speed, relative humidity, precipitation, sunshine duration, vapor pressure, and atmospheric pressure, were obtained from the China Me- 
Table 1. Area of each land-use type and their ratios (\%).

\begin{tabular}{lccccrrrrr}
\hline Land use & Forestland & Shrubland & Grassland & Cropland & Orchard & $\begin{array}{r}\text { Building } \\
\text { land }\end{array}$ & Waters & Wetland & Total \\
\hline Area $\left(10^{5} \mathrm{hm}^{2}\right)$ & 3.66 & 0.31 & 0.72 & 42.80 & 2.61 & 7.02 & 2.91 & 1.83 & 61.85 \\
$\%$ & 5.91 & 0.49 & 1.17 & 69.20 & 4.21 & 11.35 & 4.70 & 2.95 & 100 \\
\hline
\end{tabular}

teorological Data Sharing Service System (China Meteorological Administration, 2000-2012).

The statistics data for the plain from 2000 to 2012, including crop yield, crop acreage and fertilization, were obtained from Hebei economic statistical yearbooks; and the data for water withdrawal were obtained from the water resources bulletins and relevant statistical yearbooks. The landuse map of the HSP for 2012 (Fig. 2) was drawn based off of spot satellite images and a topographic map (1:10000). The main land-use types include cropland, urban, forestland, water, orchard, wetland, grassland and shrubland (Table 1).

The crop structure data were produced based on remote sensing data for this study area from 2000 to 2012 (Table 2), which included MODIS NDVI (MOD13Q1), Terra/MODIS (MOD12Q1), and Landsat TM/ETM with spatial resolutions of 250,1000, and $30 \mathrm{~m}$, respectively. Pan et al. (2015) and H. Y. Wang et al. (2015) presented the details of this method. Compared with 2000, the crop planting area changed considerably; specifically, the planting area of winter maize-summer maize decreased by $34.76 \%$, rice decreased by $31.61 \%$, spring maize increased by $34.13 \%$, vegetables increased by $26.05 \%$, and fruiters increased by $33.04 \%$, while cotton, peanut and others had a slight change, and the total cultivated area in HSP decreased by $12.58 \%$ in 2012 (Table 2).

\subsection{Crop structure scenarios setting}

The baseline for the crop structure (2012) in the HSP consisted of $42.44 \%$ of winter wheat-summer maize rotation, $11.50 \%$ of spring maize, $18.65 \%$ of vegetables, $5.75 \%$ of fruiters, $12.35 \%$ of cotton, $5.51 \%$ of peanut, $0.66 \%$ of rice, and $3.15 \%$ of others (side crops, i.e., millet, sorghum, sweet potato and others). Taking into consideration the crop structure change from 2000 to 2012, the high groundwater usage for rice and winter wheat per unit and the local residents' pasta-based diet, eight different crop structure planning scenarios were formulated, with the cotton, peanut and side crops cultivating areas unchanged (Table 3 ). These scenarios involved reducing winter wheat-summer maize and rice cultivating area to 40 and $0 \%$, respectively, and increasing spring maize cultivating area to $13.94 \%$ (scenario 1); reducing winter wheat-summer maize to $30 \%$ and increasing spring maize to $23.94 \%$ (scenario 2); reducing winter wheat-summer maize to $20 \%$ and increasing spring maize to $33.94 \%$ (scenario 3); reducing winter wheat-summer maize

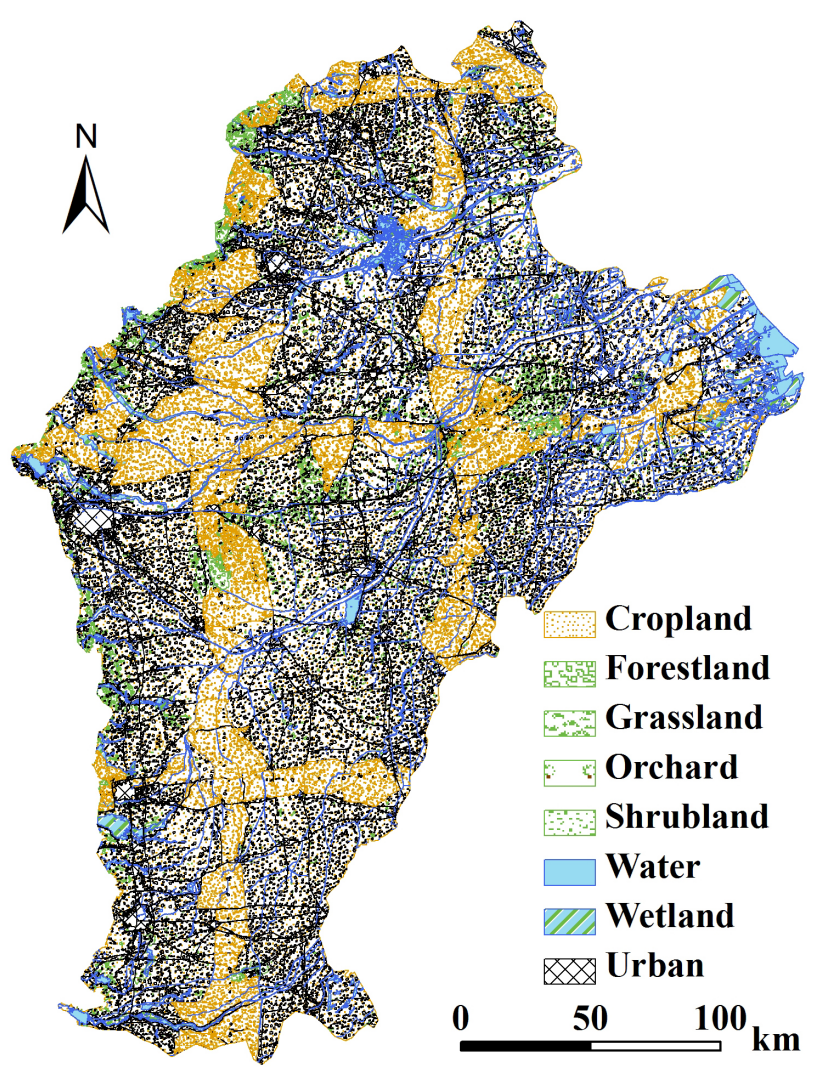

Figure 2. Land-use map of the Hebei southern plain.

to $10 \%$ and increasing spring maize to $43.94 \%$ (scenario 4 ); reducing winter wheat-summer maize to 0 and increasing spring maize to $53.94 \%$ (scenario 5); reducing winter wheat-summer maize to $20 \%$ and increasing spring maize to $38.99 \%$, and adjusting vegetables and fruiters to $10 \%$ (scenario 6); reducing winter wheat-summer maize to $20 \%$, and increasing spring maize to $28.99 \%$, vegetables to $20 \%$ and fruiters to $10 \%$ (scenario 7); reducing winter wheat-summer maize to $20 \%$, increasing spring maize to $28.99 \%$, decreasing vegetables to $10 \%$ and increasing fruiters to $20 \%$ (scenario 8).

\subsection{WF evaluation}

The WF of a crop production is the sum of the green, blue and grey water footprints (Chapagain et al., 2006). The WF of seven primary types of crops planted in the HSP is calculated 
Table 2. Planting areas $\left(10^{5} \mathrm{hm}^{2}\right)$ for the main crops and their percent change.

\begin{tabular}{lrrrrrrrrr}
\hline Year & $\begin{array}{r}\text { Winter } \\
\text { wheat- } \\
\text { summer } \\
\text { maize }\end{array}$ & $\begin{array}{r}\text { Spring } \\
\text { maize }\end{array}$ & Vegetables & Fruiters & Cotton & Peanut & Rice & Others & Total \\
& 29.54 & 3.89 & & & & & & & \\
\hline 2000 & 25.20 & 3.67 & 7.46 & 2.05 & 5.15 & 2.69 & 0.49 & 1.54 & 48.23 \\
2001 & 22.79 & 3.91 & 6.85 & 2.26 & 7.27 & 2.47 & 0.45 & 1.41 & 47.41 \\
2002 & 24.40 & 3.76 & 7.09 & 2.03 & 2.82 & 3.26 & 0.39 & 1.87 & 45.63 \\
2003 & 24.11 & 4.89 & 7.27 & 1.86 & 3.45 & 2.86 & 0.34 & 1.64 & 46.42 \\
2004 & 24.64 & 3.40 & 7.20 & 2.15 & 5.04 & 2.59 & 0.31 & 1.48 & 46.82 \\
2005 & 24.69 & 4.41 & 6.96 & 1.76 & 4.24 & 2.51 & 0.30 & 1.43 & 46.31 \\
2006 & 22.37 & 5.25 & 6.89 & 2.14 & 6.99 & 2.48 & 0.45 & 1.42 & 48.00 \\
2007 & 24.31 & 4.18 & 7.43 & 2.36 & 4.62 & 2.68 & 0.32 & 1.53 & 47.43 \\
2008 & 25.19 & 3.64 & 7.25 & 2.25 & 3.74 & 2.61 & 0.31 & 1.49 & 46.49 \\
2009 & 23.24 & 4.85 & 7.20 & 2.12 & 3.99 & 2.59 & 0.31 & 1.48 & 45.79 \\
2010 & 20.65 & 4.36 & 7.54 & 1.94 & 5.74 & 2.72 & 0.33 & 1.55 & 44.83 \\
2011 & 19.27 & 5.22 & 8.47 & 2.61 & 5.61 & 2.50 & 0.30 & 1.43 & 45.41 \\
2012 & -34.76 & 34.13 & 26.05 & 33.04 & 0.39 & 2.64 & -31.61 & 3.27 & -12.58 \\
Change (\%) & & & & & & & & \\
\hline
\end{tabular}

Table 3. Crop structure planning scenarios for the Hebei southern plain.

\begin{tabular}{|c|c|c|c|c|c|c|c|c|c|c|}
\hline \multicolumn{2}{|c|}{ Crop structure } & \multirow{2}{*}{$\begin{array}{r}\begin{array}{r}\text { Winter } \\
\text { wheat- } \\
\text { summer } \\
\text { maize }\end{array} \\
19.27 \\
42.44\end{array}$} & \multirow{2}{*}{$\begin{array}{r}\text { Spring } \\
\text { maize } \\
\\
5.22 \\
11.50\end{array}$} & \multirow{2}{*}{$\begin{array}{r}\text { Vegetables } \\
\\
8.47 \\
18.65\end{array}$} & \multirow{2}{*}{$\begin{array}{l}\text { Fruiters } \\
\\
2.61 \\
5.75\end{array}$} & \multirow{2}{*}{$\begin{array}{r}\text { Cotton } \\
\\
\\
5.61 \\
12.35\end{array}$} & \multirow{2}{*}{$\begin{array}{c}\text { peanut } \\
\\
2.50 \\
5.51\end{array}$} & \multirow{2}{*}{$\begin{array}{r}\text { Rice } \\
\\
\\
0.30 \\
0.66\end{array}$} & \multirow{2}{*}{$\begin{array}{r}\text { Others } \\
\\
1.43 \\
3.15\end{array}$} & \multirow{2}{*}{$\begin{array}{r}\text { Total } \\
\\
\\
45.41 \\
100\end{array}$} \\
\hline Baseline & $\begin{array}{c}\text { Area }\left(10^{5} \mathrm{hm}^{2}\right) \\
\%\end{array}$ & & & & & & & & & \\
\hline Scenario 1 & $\begin{array}{c}\text { Area }\left(10^{5} \mathrm{hm}^{2}\right) \\
\%\end{array}$ & $\begin{array}{l}18.16 \\
40.00\end{array}$ & $\begin{array}{r}6.33 \\
13.94\end{array}$ & $\begin{array}{r}8.47 \\
18.65\end{array}$ & $\begin{array}{l}2.61 \\
5.75\end{array}$ & $\begin{array}{r}5.61 \\
12.35\end{array}$ & $\begin{array}{l}2.50 \\
5.51\end{array}$ & $\begin{array}{l}0 \\
0\end{array}$ & $\begin{array}{l}1.43 \\
3.15\end{array}$ & $\begin{array}{r}45.41 \\
100\end{array}$ \\
\hline Scenario 2 & $\begin{array}{c}\text { Area }\left(10^{5} \mathrm{hm}^{2}\right) \\
\%\end{array}$ & $\begin{array}{l}13.62 \\
30.00\end{array}$ & $\begin{array}{l}10.87 \\
23.94\end{array}$ & $\begin{array}{r}8.47 \\
18.65\end{array}$ & $\begin{array}{l}2.61 \\
5.75\end{array}$ & $\begin{array}{r}5.61 \\
12.35\end{array}$ & $\begin{array}{l}2.50 \\
5.51\end{array}$ & $\begin{array}{l}0 \\
0\end{array}$ & $\begin{array}{l}1.43 \\
3.15\end{array}$ & $\begin{array}{r}45.41 \\
100\end{array}$ \\
\hline Scenario 3 & $\begin{array}{c}\text { Area }\left(10^{5} \mathrm{hm}^{2}\right) \\
\%\end{array}$ & $\begin{array}{r}9.08 \\
20.00\end{array}$ & $\begin{array}{l}15.41 \\
33.94\end{array}$ & $\begin{array}{r}8.47 \\
18.65\end{array}$ & $\begin{array}{l}2.61 \\
5.75\end{array}$ & $\begin{array}{r}5.61 \\
12.35\end{array}$ & $\begin{array}{l}2.50 \\
5.51\end{array}$ & $\begin{array}{l}0 \\
0\end{array}$ & $\begin{array}{l}1.43 \\
3.15\end{array}$ & $\begin{array}{r}45.41 \\
100\end{array}$ \\
\hline Scenario 4 & $\begin{array}{c}\text { Area }\left(10^{5} \mathrm{hm}^{2}\right) \\
\%\end{array}$ & $\begin{array}{r}4.54 \\
10.00\end{array}$ & $\begin{array}{l}19.95 \\
43.94\end{array}$ & $\begin{array}{r}8.47 \\
18.65\end{array}$ & $\begin{array}{l}2.61 \\
5.75\end{array}$ & $\begin{array}{r}5.61 \\
12.35\end{array}$ & $\begin{array}{l}2.50 \\
5.51\end{array}$ & $\begin{array}{l}0 \\
0\end{array}$ & $\begin{array}{l}1.43 \\
3.15\end{array}$ & $\begin{array}{r}45.41 \\
100\end{array}$ \\
\hline Scenario 5 & $\begin{array}{c}\text { Area }\left(10^{5} \mathrm{hm}^{2}\right) \\
\%\end{array}$ & $\begin{array}{l}0 \\
0\end{array}$ & $\begin{array}{l}24.49 \\
53.94\end{array}$ & $\begin{array}{r}8.47 \\
18.65\end{array}$ & $\begin{array}{l}2.61 \\
5.75\end{array}$ & $\begin{array}{r}5.61 \\
12.35\end{array}$ & $\begin{array}{l}2.50 \\
5.51\end{array}$ & $\begin{array}{l}0 \\
0\end{array}$ & $\begin{array}{l}1.43 \\
3.15\end{array}$ & $\begin{array}{r}45.41 \\
100\end{array}$ \\
\hline Scenario 6 & $\begin{array}{c}\text { Area }\left(10^{5} \mathrm{hm}^{2}\right) \\
\%\end{array}$ & $\begin{array}{r}9.08 \\
20.00\end{array}$ & $\begin{array}{l}17.71 \\
38.99\end{array}$ & $\begin{array}{r}4.54 \\
10.00\end{array}$ & $\begin{array}{r}4.54 \\
10.00\end{array}$ & $\begin{array}{r}5.61 \\
12.35\end{array}$ & $\begin{array}{l}2.50 \\
5.51\end{array}$ & $\begin{array}{l}0 \\
0\end{array}$ & $\begin{array}{l}1.43 \\
3.15\end{array}$ & $\begin{array}{r}45.41 \\
100\end{array}$ \\
\hline Scenario 7 & $\begin{array}{c}\text { Area }\left(10^{5} \mathrm{hm}^{2}\right) \\
\%\end{array}$ & $\begin{array}{r}9.08 \\
20.00\end{array}$ & $\begin{array}{l}13.16 \\
28.99\end{array}$ & $\begin{array}{r}9.08 \\
20.00\end{array}$ & $\begin{array}{r}4.54 \\
10.00\end{array}$ & $\begin{array}{r}5.61 \\
12.35\end{array}$ & $\begin{array}{l}2.50 \\
5.51\end{array}$ & $\begin{array}{l}0 \\
0\end{array}$ & $\begin{array}{l}1.43 \\
3.15\end{array}$ & $\begin{array}{r}45.41 \\
100\end{array}$ \\
\hline Scenario 8 & $\begin{array}{c}\text { Area }\left(10^{5} \mathrm{hm}^{2}\right) \\
\%\end{array}$ & $\begin{array}{r}9.08 \\
20.00\end{array}$ & $\begin{array}{l}13.16 \\
28.99\end{array}$ & $\begin{array}{r}4.54 \\
10.00\end{array}$ & $\begin{array}{r}9.08 \\
20.00\end{array}$ & $\begin{array}{r}5.61 \\
12.35\end{array}$ & $\begin{array}{l}2.50 \\
5.51\end{array}$ & $\begin{array}{l}0 \\
0\end{array}$ & $\begin{array}{l}1.43 \\
3.15\end{array}$ & $\begin{array}{r}45.41 \\
100\end{array}$ \\
\hline
\end{tabular}


separately:

$\mathrm{WF}=\sum_{a=1}^{n} \mathrm{WF}_{\mathrm{a}}$,

$\mathrm{WF}=\mathrm{WF}_{\text {blue }}+\mathrm{WF}_{\text {green }}+\mathrm{WF}_{\text {grey }}$,

where WF is the total water footprint $\left(\mathrm{m}^{3} \mathrm{yr}^{-1}\right) ; \mathrm{WF}_{\mathrm{a}}$ is the water footprint of each type of crop in the HSP; $\mathrm{WF}_{\text {blue }}$ is the blue water footprint $\left(\mathrm{m}^{3} \mathrm{yr}^{-1}\right)$; $\mathrm{WF}_{\text {green }}$ is the green water footprint $\left(\mathrm{m}^{3} \mathrm{yr}^{-1}\right)$; and $\mathrm{WF}_{\text {grey }}$ is the grey water footprint $\left(\mathrm{m}^{3} \mathrm{yr}^{-1}\right)$.

The WF intensity (WFI) of a crop production is evaluated by dividing WF by crop yield:

$\mathrm{WFI}_{\mathrm{a}}=\mathrm{WF}_{\mathrm{a}} / Y_{\mathrm{a}}$,

where $\mathrm{WFI}_{\mathrm{a}}$ is the WF intensity of a certain crop $\left(\mathrm{m}^{3} \mathrm{t}^{-1}\right)$ and $Y_{\mathrm{a}}$ is the yield of that kind of crop (t).

The green water footprint was represented by crop evaporation or effective rainfall:

$$
\begin{aligned}
& \mathrm{WF}_{\text {blue }}=10 \times \mathrm{ET}_{\text {blue }} \times A, \\
& \mathrm{WF}_{\text {green }}=10 \times \mathrm{ET}_{\text {green }} \times A, \\
& \mathrm{ET}_{\text {blue }}=\max \left\{0, \mathrm{ET}_{\mathrm{c}}-P_{\mathrm{e}}\right\}, \\
& \mathrm{ET}_{\text {green }}=\min \left\{P_{\mathrm{e}}, \mathrm{ET}_{\mathrm{c}}\right\},
\end{aligned}
$$

where $\mathrm{ET}_{\text {blue }}$ is the blue water evapotranspiration during the growth period of crops $(\mathrm{mm})$; $\mathrm{ET}_{\text {green }}$ is green water evapotranspiration $(\mathrm{mm}) ; A$ is the acreage of the calculated crop $\left(\mathrm{hm}^{2}\right) ; \mathrm{ET}_{\mathrm{c}}$ is the actual crop evapotranspiration $(\mathrm{mm})$; and $P_{\mathrm{e}}$ is the effective precipitation $(\mathrm{mm})$, which can be calculated using the Soil Conservation Service Method developed by the US Department of Agriculture (USDA).

$$
P_{\mathrm{e}}= \begin{cases}P \times(125-0.6 P) / 125 & P \leq 250 / 3 \\ 125 / 3+0.1 P & P>250 / 3\end{cases}
$$

where $P$ is the precipitation ( $\mathrm{mm})$.

$\mathrm{ET}_{\mathrm{c}}$ can be calculated based on the reference evapotranspiration $\left(\mathrm{ET}_{0}\right)$ which is estimated according to the FAO56-PM model (Allen et al., 1998):

$\mathrm{ET}_{\mathrm{c}}=K_{\mathrm{c}} \times \mathrm{ET}_{0}$,

$\mathrm{ET}_{0}=\frac{0.408 \Delta\left(R_{\mathrm{n}}-G\right)+\gamma \frac{900}{T_{\mathrm{em}}+273} u_{2}\left(e_{\mathrm{s}}-e_{\mathrm{a}}\right)}{\Delta+\gamma\left(1+0.34 u_{2}\right)}$,

where $K_{\mathrm{c}}$ is the crop coefficient, and the $K_{\mathrm{c}}$ of the crops was determined according to their growing stage (Duan, 2004); $R_{\mathrm{n}}$ is the net radiation at the vegetation surface $\left(\mathrm{MJ} \mathrm{m}^{-2}\right.$ day $\left.^{-1}\right) ; G$ is the soil heat flux density $\left(\mathrm{MJ} \mathrm{m}^{-2}\right.$ day $\left.^{-1}\right) ; T_{\mathrm{em}}$ is the daily average temperature $\left({ }^{\circ} \mathrm{C}\right)$; $u_{2}$ is the wind speed at a $2 \mathrm{~m}$ height $\left(\mathrm{m} \mathrm{s}^{-1}\right) ; e_{\mathrm{s}}$ is the vapor pressure of the air at saturation $(\mathrm{kPa}) ; e_{\mathrm{a}}$ is the actual vapor pressure $(\mathrm{kPa}) ; \Delta$ is the slope of the vapor pressure curve $\left(\mathrm{kPa}{ }^{\circ} \mathrm{C}^{-1}\right)$; and $\gamma$ is the psychrometric constant $\left(\mathrm{kPa}^{\circ} \mathrm{C}^{-1}\right)$.
Table 4. WF $\left(\mathrm{km}^{3}\right)$ and the WFI $\left(\mathrm{m}^{3} \mathrm{t}^{-1}\right)$ of each crop.

\begin{tabular}{lrrrrr}
\hline Crop types & WFgreen & WFblue & WFgrey & WF & WFI \\
\hline Winter wheat & 2.1 & 5.1 & 4.8 & 12.0 & 887.0 \\
Summer maize & 3.6 & 3.7 & 2.9 & 10.1 & 701.7 \\
Spring maize & 1.3 & 1.3 & 0.7 & 2.9 & 691.1 \\
Cotton & 0.9 & 2.1 & 0.7 & 3.8 & 1493.0 \\
Peanut & 0.5 & 0.8 & 0.2 & 1.6 & 1043.2 \\
Rice & 0.1 & 0.2 & 0.1 & 0.4 & 903.1 \\
Vegetables & 1.3 & 4.9 & 1.5 & 7.7 & 183.6 \\
Fruiters & 0.5 & 1.1 & 1.0 & 2.6 & 246.4 \\
Others & 0.2 & 0.5 & 0.2 & 0.9 & 1030.8 \\
Total & 10.1 & 19.7 & 12.0 & 41.8 & \\
\hline
\end{tabular}

A complete set of equations is proposed by Allen et al. (1998) to compute the variables in Eq. (10) according to available weather data and the time step computation, which constitute the FAO-PM method. $G$ can be ignored for daily time step computations.

Due to a lack of accessible data, the grey WF of crops only assesses nitrogen contamination without considering the effect of pesticides and other fertilizers, and was calculated by the following equation (Hoekstra et al., 2009):

$\mathrm{WF}_{\text {grey }}=\left(\delta \times U_{\mathrm{N}} \times 10^{6}\right) / \rho_{0}$,

where $U_{\mathrm{N}}$ is the applied amount of $\mathrm{N}$ fertilizer $(\mathrm{t}) . \delta$ represents the leaching rate to freshwater with values $5-15 \%$ (Zhang and Zhang, 1998) and we use the ambient water quality standard for nitrogen $\left(10 \mathrm{mg} \mathrm{L}^{-1}\right)$ as the permissible concentration $\left(\rho_{0}\right)$. Due to a lack of accessible data, we ignored pesticides and other fertilizers.

\section{Results}

\subsection{WF and WFI of crop production in 2012}

The WF of crop production in 2012 was analyzed, and the results were taken as the baseline for the crop structure analysis. The total WF of the production of crops in the HSP was approximately $41.8 \mathrm{~km}^{3}$, of which $24 \%$ was WFgreen $\left(10.1 \mathrm{~km}^{3}\right), 47 \%$ was WFblue $\left(19.7 \mathrm{~km}^{3}\right)$ and $29 \%$ was WFgrey $\left(12.0 \mathrm{~km}^{3}\right.$ ) (Table 4). We found large differences among the WF, WFgreen, WFblue and WFgrey for the main crops: wheat, maize, cotton, peanut, rice, vegetables, and fruiters. Winter wheat, summer maize and vegetables were the three leading crops in water consumption, taking $29 \%\left(12.0 \mathrm{~km}^{3}\right)$, $24 \%\left(10.1 \mathrm{~km}^{3}\right)$ and $18 \%\left(7.7 \mathrm{~km}^{3}\right)$ of the total $\mathrm{WF}$, respectively. The WF of spring maize, cotton, peanut, rice, fruiters and others was $2.9 \mathrm{~km}^{3}(7 \%), 3.8 \mathrm{~km}^{3}(9 \%), 1.6 \mathrm{~km}^{3}(4 \%)$, $0.3 \mathrm{~km}^{3}(1 \%), 2.6 \mathrm{~km}^{3}(6 \%)$ and $0.9 \mathrm{~km}^{3}(2 \%)$, respectively. The WFgreen of these crops was $2.1 \mathrm{~km}^{3}$ (accounting for $21 \%$ of the total WFgreen), $3.6 \mathrm{~km}^{3}(35 \%), 0.9 \mathrm{~km}^{3}$ $(9 \%), 0.9 \mathrm{~km}^{3}$ (9\%), $0.5 \mathrm{~km}^{3}(5 \%), 0.1 \mathrm{~km}^{3}(1 \%), 1.3 \mathrm{~km}^{3}$ 
(13\%), $0.5 \mathrm{~km}^{3}(5 \%)$, and $0.2 \mathrm{~km}^{3}(2 \%)$, respectively, of which summer maize was the largest, followed by winter wheat. The WFblue of these crops was $5.1 \mathrm{~km}^{3}$ (accounting for $26 \%$ of the total WFblue), $3.7 \mathrm{~km}^{3}(19 \%), 1.3 \mathrm{~km}^{3}$ $(7 \%), 2.1 \mathrm{~km}^{3}(11 \%), 0.8 \mathrm{~km}^{3}(4 \%), 0.2 \mathrm{~km}^{3}(1 \%), 4.9 \mathrm{~km}^{3}$ $(25 \%), 1.1 \mathrm{~km}^{3}(6 \%)$, and $0.5 \mathrm{~km}^{3}(3 \%)$, respectively, of which winter wheat was the largest, followed by vegetables. The WFgrey of these crops was $4.8 \mathrm{~km}^{3}$ (accounting for $40 \%$ of the total WFgrey), $2.9 \mathrm{~km}^{3}(24 \%), 0.7 \mathrm{~km}^{3}(5 \%), 0.7 \mathrm{~km}^{3}$ (5\%), $0.2 \mathrm{~km}^{3}$ (2\%), $0.1 \mathrm{~km}^{3}(1 \%), 1.5 \mathrm{~km}^{3}(13 \%), 1.0 \mathrm{~km}^{3}$ $(8 \%)$, and $0.2 \mathrm{~km}^{3}(2 \%)$, respectively, of which winter wheat was the largest, followed by summer maize. The situation of the WFI was totally different from the situation of the WF (Table 4). Among these crops, the WFI of cotton was the largest, and for vegetables, it was the smallest, and the former was approximately 6 times greater than the latter; the WFI of summer maize was basically equal to that of spring maize.

\subsection{Annual WF of crop production}

Over the past 13 years (2000-2012), the total WF of crop production in the HSP was $604.8 \mathrm{~km}^{3}$, comprised of $288.5 \mathrm{~km}^{3}$ WFblue, $141.3 \mathrm{~km}^{3}$ WFgreen and $175.0 \mathrm{~km}^{3}$ WFgrey, and decreased by $22 \%$ (from 53.7 to $41.8 \mathrm{~km}^{3}$ ), $26 \%$ (from 26.5 to $19.7 \mathrm{~km}^{3}$ ), $14 \%$ (from 11.7 to $10.1 \mathrm{~km}^{3}$ ), and $23 \%$ (from 15.5 to $12.0 \mathrm{~km}^{3}$ ), respectively, from 2000 to 2012 (Fig. 3). The main reasons for the downtrend of the WF were the urbanization of farmland and the decrease in the winter wheat planting area. In addition, the total WFblue of these crops was approximately twice the amount of the total WFgreen, and the total WFgrey was slightly more than the total WFgreen.

Table 5 shows the WF of each crop over 13 years. Winter wheat, summer maize and vegetables are the three leading crops for water usage, taking 33, 28 and $16 \%$ of the total WF, respectively. Notably, summer maize accounted for $42 \%$ of WFgreen, $22 \%$ of WFblue and $27 \%$ of WFgrey; winter wheat accounted for $21 \%$ of WFgreen, $31 \%$ of WFblue and $44 \%$ of WFgrey; and vegetables accounted for $11 \%$ of WFgreen, $22 \%$ of WFblue and $11 \%$ of WFgrey (Table 5).

\subsection{Scenario analysis of WF for different crop structure}

Results from the eight scenarios (Table 6) illustrated the following: (1) the WF (comprised of WFgreen, WFblue and WFgrey) of all the scenarios was smaller than the baseline, and those of scenario 5 were the smallest in the eight scenarios; (2) the WFs of scenario 3 and scenario 6 were essentially equal, as were scenario 7 and scenario 8; (3) the WF reduced from scenario 1 to scenario 5 as the planting area of winter wheat and summer maize rotation decreased to zero and spring maize increased to $53.94 \%$; (4) the WFgreen of sce-
Table 5. WF $\left(\mathrm{km}^{3}\right)$ of each crop in the HSP from 2000 to 2012.

\begin{tabular}{lrrrr}
\hline Crop types & WFgreen & WFblue & WFgrey & WF \\
\hline Winter wheat & 30.0 & 89.1 & 77.6 & 196.7 \\
Summer maize & 58.8 & 62.6 & 46.6 & 168.0 \\
Spring maize & 10.5 & 13.8 & 6.9 & 31.2 \\
Cotton & 11.9 & 24.4 & 8.0 & 44.3 \\
Peanut & 6.2 & 12.8 & 3.4 & 22.4 \\
Rice & 0.8 & 3.5 & 0.9 & 5.2 \\
Vegetables & 15.4 & 62.3 & 18.7 & 96.4 \\
Fruiters & 4.8 & 12.5 & 10.3 & 27.7 \\
Others & 2.8 & 7.5 & 2.6 & 12.9 \\
Total & 141.4 & 288.5 & 175.1 & 604.8 \\
\hline
\end{tabular}

Table 6. WF $\left(\mathrm{km}^{3}\right)$ of different crop structure scenarios in the Hebei southern plain.

\begin{tabular}{lrrrr}
\hline $\begin{array}{l}\text { Crop } \\
\text { structure }\end{array}$ & WFgreen & WFblue & WFgrey & WF \\
\hline Baseline & 10.1 & 19.7 & 12.0 & 41.8 \\
Scenario 1 & 9.9 & 19.2 & 11.7 & 40.8 \\
Scenario 2 & 9.4 & 18.3 & 10.4 & 38.1 \\
Scenario 3 & 8.9 & 17.4 & 9.2 & 35.4 \\
Scenario 4 & 8.4 & 16.4 & 7.9 & 32.7 \\
Scenario 5 & 7.9 & 15.6 & 6.7 & 30.3 \\
Scenario 6 & 9.1 & 16.8 & 9.6 & 35.5 \\
Scenario 7 & 9.1 & 18.6 & 9.9 & 37.6 \\
Scenario 8 & 9.2 & 17.6 & 10.7 & 37.5 \\
\hline
\end{tabular}

narios 2, 3, 6, 7 and 8 were nearly equal, and the value was approximately $9 \mathrm{~km}^{3}$.

\section{Discussions}

\subsection{Crop water consumption}

In the HSP, irrigation water has been the primary source of water for agricultural needs (Yuan and Shen, 2013), which was confirmed in this study. According to the above analysis, water consumption of crops mainly came from irrigation, and their WFblue accounted for approximately $50 \%$ of the WF (Tables 4 and 5). Although irrigation can directly increase crop yields, it also usually increases the crop WF (da Silva et al., 2013). In areas of water shortage, improving water use efficiency to reduce groundwater exploitation is imperative. Deficit irrigation has been widely used to save groundwater resources in the NCP (Ma et al., 2013) by taking better account of crop yield and water consumption.

During the 13 years, the WFblue of winter wheat was the largest of these crops, followed by summer maize, and then vegetables, which indicates that winter wheat, summer maize and vegetables consumed a large amount of groundwater. The WFblue of the crops, apart from summer maize 


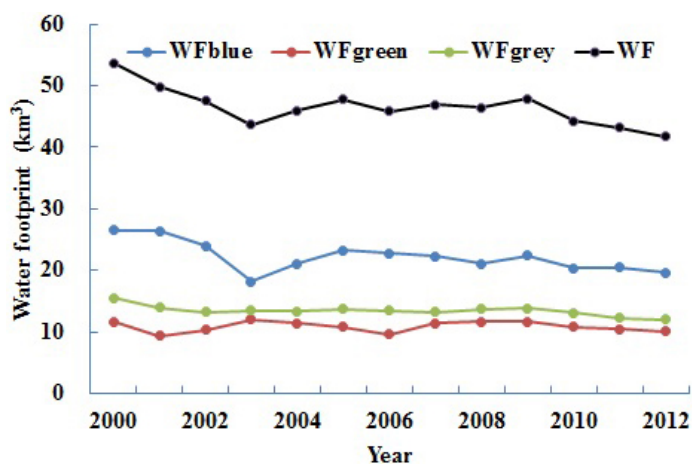

Figure 3. WF of crop production in the HSP from 2000 to 2012.

and spring maize, was more than double their WFgreen; furthermore, the WFblue of rice and vegetables was more than quadruple their WFgreen. The WFgreen of both summer maize and spring maize were approximately equal to their WFblue. This was because the rapid growth stage of maize was basically synchronized with the rainy season (July to September) in this region, and the precipitation was able to meet the needs of crop growth in this period. Therefore, in arid and semi-arid areas, cultivating rain-fed crops is an effective approach to saving groundwater, while for other crops, the precipitation cannot meet their needs. Therefore, water for these crops needs to come mainly from irrigation.

\subsection{WF responses to crop structure}

Crop structure affects the water consumption directly. The above analysis shows that, with the decrease in winter wheatsummer maize rotation planting area and the increase in spring maize (scenario 1 to scenario 5), the WF (comprised of WFgreen, WFblue and WFgrey) decreased (Table 6). Specifically, when the area of winter wheat-summer maize decreased by $10 \%$ and spring maize increased by $10 \%$ (relative to the total farmland area), the average WF, WFgreen, WFblue and WFgrey decreased by 7.2, 5.4, 5.1 and $12.8 \%$, respectively. However, since wheat is a staple food in the HSP and a ration crop, and this region needs to guarantee food self-sufficiency, areas should still be planted with winter wheat, despite its large consumption of water resources. Vegetables had a low-level WFI; however, the water consumption of vegetables per unit area was much more than with other crops (scenario 6 and scenario 7). Despite this, the HSP should protect the basic supply of vegetables and fruits for Beijing, Tianjin and Hebei Province. Planting and keeping certain areas with vegetables and fruiters is necessary.

Changes to crop structure directly affect irrigation consumption (or WFblue) and indirectly affect the emissions of environmental pollutants that can be measured by WFgrey. In the study area, water consumption for crops is primarily attributable to groundwater irrigation. It is imperative to identify a reasonable crop structure by considering the sustainable use of groundwater and the lifestyle of local people. According to the above scenario analysis, we found the crop structure of scenario 6 to be reasonable. Because this structure can guarantee regional self-sufficiency, food, including vegetables, fruits, cotton, and peanuts, and the groundwater consumption of this structure were acceptable. In addition, policies on agricultural crop structure optimization should be encouraged, with the aim of relieving the pressure on groundwater for crop production and ensuring food security in this region. In recent years, winter wheat and summer maize have been replaced by spring crops in many places of the HSP. This was called "the spring corn planting belt phenomenon" (Feng et al., 2007; Huang et al., 2012; X. Wang et al., 2014). Clearly, this phenomenon can help in the restoration of groundwater resources in this region.

\subsection{Main uncertainties of this study}

First, the estimation of WF (comprised of WFgreen, WFblue and WFgrey) was affected by crop distribution, in regards to the spatial differences of underlying surface conditions, climatic conditions and irrigation conditions. The crop structure scenarios only considered the crop planting areas and did not take into account the crop distribution. In addition, the parameter of $P_{\mathrm{e}}$ can affect the WFgreen and WFblue values because it was calculated by an empirical formula, and the WFgrey only considered nitrogen contamination and ignored pesticides and other fertilizers, therefore, the calculated WFgrey, WFgreen, WFblue and WF had a certain deviation compared with the actual values. Second, the scenarios had a certain degree of randomness since there was no consideration of changes in planting areas of cotton, peanut and others (Table 2). For example, with cotton lacking a high market value and having difficulties in its management (e.g., requiring artificial picking), its growing area was likely shrinking, and its distribution was changing. Third, due to the urbanization in this region, the area of arable land has been shrinking; likewise, some arable land was abandoned because many rural young people went to work in cities. Our scenario analysis, however, did not take into account these phenomena, as we lacked the corresponding data. Fourth, climatic variability has major effects on crop WF (Sun et al., 2010; Bocchiolaet al., 2013; Yang et al., 2013), and many researchers have found that this region has undergone an upward trend of temperatures and a declining trend of precipitation since the 1960s (Hu et al., 2002; Yuan et al., 2009; Sun et al., 2010). If precipitation continues to decline while temperature increases over time, these climatic developments will certainly affect the WF for crop production. These effects are worth an in-depth analysis, which could provide valuable information for water resource management. 


\section{Conclusions}

This study analyzed the WF of crop production in the HSP and evaluated its temporal variation from 2000 to 2012. Over 13 years, the production of main crops consumed a total of approximately $604.8 \mathrm{~km}^{3}$ of water, of which $288.5 \mathrm{~km}^{3}$ was groundwater; additionally, the WF of the production of crops exhibited a downtrend yearly. Among the local main crops, winter wheat, summer maize and vegetables were the three leading crops in water consumption; their WF, WFblue, WFgreen and WFgrey accounted for 76.2, 73.7, 74.2 and 81.6\% of the total, respectively.

In this region, adjusting crop farming structures has been an important means of protecting groundwater resources; therefore, we evaluated reasonable farming structures by analyzing scenarios of the main crops' WF in this plain and suggest that scenario 6 with approximately $20 \%$ of the arable land in cultivation of winter wheat-summer maize in rotation, $38.99 \%$ of spring maize, $10 \%$ of vegetables, $10 \%$ of fruiters, $0 \%$ of rice and no change to other crops will promote the sustainable development of agriculture in this region. This scenario can not only protect approximately $14.5 \%$ of groundwater resources (compared to the baseline), but can also ensure the local supply of wheat, vegetables, and fruits.

Data availability. All the data relevant to this paper can be found in its Supplement.

\section{The Supplement related to this article is available online at https://doi.org/10.5194/hess-21-3061-2017- supplement.}

Competing interests. The authors declare that they have no conflict of interest.

Acknowledgements. This paper was supported by the Natural Science Foundation of China (40901130, 41471027), the high-level leading talent introduction program of GDAS (2060599), the Research Team of the Guangdong Natural Science Foundation (S2012030006144), the SPICC Program (2016GDASPT-0105), the Construction of Innovative Talents for Pollution Control and Management of Heavy Metals in Farmland (2016B070701015), the Innovation-driven Development Capability Construction Program of GDAS (2017GDASCX-0106), the Science and Technology Project of Hebei Province (16454203D) and the Social Science Foundation of Hebei Province (HB15GL083). We are also grateful to the reviewers and editors.

Edited by: B. Hu

Reviewed by: three anonymous referees
References

Allen, R. G., Pereira, L. S., Raes, D., and Smith, M.: Crop evapotranspiration-Guidelines for computing crop water requirements, FAO Irrigation and drainage paper 56, FAO, Rome, Italy, 1998.

Bocchiola, D., Nana, E., and Soncini, A.: Impact of climate change scenarios on crop yield and water footprint of maize in the Po valley of Italy, Agr. Water Manage., 116, 50-61, 2013.

Chapagain, A. K. and Hoekstra, A. Y.: The blue, green and grey water footprint of rice from production and consumption perspectives, Ecol. Econ., 70, 749-758, 2011.

Chapagain, A. K. and Orr, S.: An improved water footprint methodology linking global consumption to local water resources: a case of Spanish tomatoes, J. Environ. Manage., 90, 1219-1228, 2009.

Chapagain, A. K., Hoekstra, A. Y., Savenije, H. H. G., and Gautam, R.: The water footprint of cotton consumption: an assessment of the impact of worldwide consumption of cotton products on the water resources in the cotton producing countries, Ecol. Econ., 60, 186-203, 2006.

Chen, J. Y., Tang, C. Y., Shen, Y. J. Sakura, Y., Kondoh, A., and Shimada, J.: Use of water balance calculation and tritium to examine the dropdown of groundwater table in the piedmont of the North China Plain (NCP), Environ. Geol. , 44, 564-571, 2003.

China Meteorological Administration (CMA): available at: http:// www.cma.gov.cn/ (last access: 20 June 2017), 2000-2012.

da Silva, V. D. P. R., da Silva, B. B., Albuquerque, W. G., Borges, C. J. R., de Sousa, I. F., and Neto, J. D.: Crop coefficient, water requirements, yield and water use efficiency of sugarcane growth in Brazil, Agr. Water Manage., 128, 102-109, 2013.

Dong, H., Geng, Y., Sarkis, J., Fujita, T., Okadera, T., and Xue, B.: Regional water footprint evaluation in China: A case of Liaoning, Sci. Total Environ., 442, 215-224, 2013.

Duan, A. W.: Irrigation water quota of main crops in North China, Agricultural Science and Technology Press of China, Beijing, 2004.

Feng, Z. M., Liu, D. W., and Zhang, Y. H.: Water requirements and irrigation sched-uling of spring maize using GIS and CropWat model in Beijing-Tianjin-Hebei region, Chin. Geogr. Sci., 17, 56-63, 2007.

Gheewala, S. H., Silalertruksa, T., Nilsalab, P., Mungkung, R., Perret, S. R., and Chaiyawannakarn, N.: Water footprint and impact of water consumption for food, feed, fuel crops production in Thailand, Water, 6, 1698-1718, 2014.

Gleick, P. H.: Global freshwater resources: soft-path solutions for the 21st century, Science, 302, 1524-1528, 2003.

Hoekstra, A. Y. (Ed.): Virtual Water Trade, in: Proceedings of the International Expert Meeting on Virtual Water Trade, 1213 December 2002, Delft, the Netherlands, Value of Water Research Report Series No. 12, UNESCO-IHE, Delft, the Netherlands, available at: http://waterfootprint.org/media/downloads/ Report12.pdf (last access: 20 June 2017), 2003.

Hoekstra, A. Y. and Chapagain, A. K.: Water footprints of nations: water use by people as a function of their consumption pattern, Water Resour. Manage., 21, 35-48, 2007.

Hoekstra, A. Y., Chapagain, A. K., Aldaya, M. M., and Mekonnen, M. M.: Water Footprint Manual: State of the Art, Water Footprint Network, Enschede, the Netherlands, 2009. 
Hu, C. S., Zhang, X. Y., Cheng, Y. S., and Pei, D.: An analysis on dynamics of water tableand overdraft in the piedmont of Mt Taihang, Syst. Sci. Compr. Stud. Agric., 18, 89-91, 2002.

Huang, J., Bradley, G. R., Xu, C. C., Zhang, H. L., and Chen, F.: Cropping pattern mod-ifications change water resource demands in the Beijing metropolitan area, J. Integr. Agric., 11, 1914-1923, 2012.

Jefferies, D., Muñoz, I., Hodges, J., King, V. J., Aldaya, M., Ercin, A. E., Canals, L. M., and Hoekstra, A. Y.: Water footprint and life cycle assessment as approaches to assess potential impacts of products on water consumption. Key learning points from pilot studies on tea and margarine, J. Clean. Prod., 33, 155-166, 2012.

Konar, M., Dalin, C., Suweis, S., Hanasaki, N., Rinaldo, A., and Rodriguez-Iturbe, I.: Water for food: the global virtual water trade network, Water Resour. Res., 47, 143-158, https://doi.org/10.1029/2010WR010307, 2011.

Lamastra, L., Suciu, N. A., Novelli, E., and Trevisan, M.: A new approach to assessing the water footprint of wine: an Italian case study, Sci. Total Environ., 490, 748-756, 2014.

Lucrezia, L., Nicoleta, A. S., Elisa, N., and Marco, T.: A new approach to assessing the water footprint of wine: An Italian case study, Sci. Total Environ., 490, 748-756, 2014.

Ma, Y., Feng, S., and Song, X.: A root zone model for estimating soil water balance and crop yield responses to deficit irrigation in the North China Plain, Agr. Water Manage., 127, 13-24, 2013.

Mekonnen, M. M. and Hoekstra, A. Y.: The green, blue and grey water footprint of crops and derived crop products, Value ofwater research report series No. 47, UNESCO-IHE, Delft, the Netherlands, 2010

Pan, X. P., Li, G. X., Liu, F. G., Wu, X. F., Kondoh, A., and Shen, Y. J.: Using remote sensing to determine spatio-temporal variations in winter wheat growing area in the North China Plain, Chin. J. Eco-Agric., 23, 497-505, 2015.

Rosegrant, M. W. and Ringler, C.: Impact on food security and rural developmentof transferring water out of agriculture, Water Policy, 1, 567-586, 2000.

Shrestha, S., Pandey, V. P., Chanamai, C., and Ghosh, D. K.: Green, blue and grey water footprints of primary crops production in Nepal, Water Resour. Manage., 27, 5223-5243, https://doi.org/10.1029/2010WR010307, 2013.

Sun, H., Shen, Y., Yu, Q., Flerchinger, G. N., Zhang, Y., Liu, C., and Zhang, X.: Effect ofprecipitation change on water balance and WUE of the winter wheat-summermaize rotation in the North China Plain, Agr. Water Manage., 97, 1139-1145, 2010.
Suttayakul, P., H-Kittikun, A., Suksaroj, C., Mungkalasiri, J., Wisansuwannakorn, R., and Musikavong, C.: Water footprints of products of oil palm plantations and palm oil mills in Thailand, Sci Total Environ., 542, 521-529, 2016.

UNEP: Global Environment Outlook e Geo 4: Environment for Development, United Nations Environment Programme, Valletta, Malta, 2007.

Wang, H. Y., Pan, X. P., Luo, J. M., Luo, Z. P., Chang, C. P., and Shen, Y. J.: Using remote sensing to analyze spatiotemporal variations in crop planting in the North China Plain, Chin. J. EcoAgricult., 23, 1199-1209, 2015.

Wang, X., Li, X., and Xin, L.: Impact of the shrinking winter wheat sown area onagricultural water consumption in the Hebei Plain, J. Geogr. Sci., 24, 313-330, 2014.

Wang, X., Li, X. B., and Fischer, G.: Impact of the changing area sown to winter wheat on crop water footprint in the North China Plain, Ecol. Indicat., 57, 100-109, 2015.

Wang, Y. B., Wu, P. T., Engel, B. A., and Sun, S. K.: Application of water footprint combined with unified virtual crop pattern to evaluate crop water productivity in grain production in China, Sci. Total Environ., 497-498, 1-9, 2014.

White, D. J., Feng, K. S., Sun, L. X., and Hubacek, K.: A hydroeconomic MRIO analysis of the Haihe River Basin's water footprint and water stress, Ecol. Model., 318, 157-167, 2015.

Xu, Y. J., Huang, K., Yu, Y. J., and Wang, X. M.: Changes in water footprint of crop production in Beijing from 1978 to 2012: a logarithmic mean Divisia index decomposition analysis, J. Clean. Prod., 87, 180-187, 2014.

Yang, X., Gao, W., Shi, Q., Chen, F., and Chu, Q.: Impact of climate change on thewater requirement of summer maize in the HuangHuai-Hai farming region, Agr Water Manage., 124, 20-27, 2013.

Yuan, Z. J. and Shen, Y. J.: Estimation of Agricultural Water Consumption from Meteorological and Yield Data: A Case Study of Hebei, North China, PLOS ONE, 8, e58685, https://doi.org/10.1371/journal.pone.0058685, 2013.

Yuan, Z. J., Shen, Y. J., Chu, Y. M., and Qi, Y. Q.: Variations and distribution of temperature and precipitation of Haihe River Basin in recent 40 years, Res. Soil Water Conserv., 16, 24-26, 2009.

Zang, T., Xie, X., and Huang, Z.: Life cycle water footprints of nonfood biomass fuels in China, Environ. Sci. Technol., 48, 41374144, 2014.

Zhang, G. and Zhang, S.: Advances in agricultural nitrogen leaching in soil, Soil, 6, 291-297, 1998. 